\title{
DRAINAGE AS A FACTOR IN INCREASING PRODUCTION
}

By A. W. HUDSON, Professor of Field Husbandry, Massey Agricultural College, Palmerston North.

\section{INTRODUCTION}

When I was asked to give a paper on farm drainage at the 1951 Grassland Conference my first thought was that Taranaki, with its pervious volcanic soils, was hardly the place in which such a paper would be of interest. I have since changed my mind in this connection after having had a quick visit to the Uruti district to inspect drainage carried out by $\mathrm{Mr}$ Butler near Inglewood, to see some excellent results of drainage by Mr Fox (Okahu Rd., Okato), whose herd has been increased from 35 cows to 130 over the past 26 years, largely, and basically, as a result of drainage, and also to inspect, somewhat hurriedly, a very large area on the western side of Mt. Egmont where drainage is the key to the development of country which, in its present condition is contributing little or nothing to production.

\section{The Importance of Farm Drainage}

"With further pasture improvement, particularly by drainage in the case of the North Island, dairy production can be very considerably increased. Drainage is probably the most effective single operation for increasing production on our better land."

This statement was made by no less a person than Mr A. P. O'Shea, General Secretary of New Zealand Federated Farmers.

I agree with it! It must not be inferred, however, that drainage alone would be all that would be required in the development of much of our wet country.

The point is that drainage is the first essential in the full exploitation of lime (where needed), fertilisers, improved strains of grasses and clovers, good crops, and the proper utilisation of pastures and crops.

The extreme importance of drainage was recognized by the British Government when, during the 
Second World War and since, a subsidy of up to 50 per cent. of the cost has been allowed, under certain conditions, on farm drainage. The conditions are that schemes must be approved, and the amount of subsidy is limited to $.30 \mathrm{~s}$. per acre in the case of mole draining and $\mathfrak{f} 710 \mathrm{~s}$. per acre for tile drains: Could a more fitting recognition of the importance of land drainage be provided? I do not wish to imply that land drainage -in New Zealand should be subsidised-it can stand on its own merits-but I have referred to the British subsidy with the idea. of drawing a comparison between Britain's attitude and our own, to land drainage. During the war field tiles sold in New Zealand carried a sales tax, while Britain was subsidising drainage to assist in the production of essential foodstuffs. Fortunately field tiles are now exempt from sales tax in New Zealand.

\section{Tile Prices}

Tile prices, like those of other articles, have increased considerably and including rail and cartage from rail are approximately as follows:-

\section{Cost of 100 tiles landed on the farm}

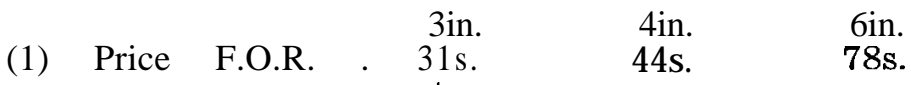

$\begin{array}{cccc}31 \mathrm{~s} . & 44 \mathrm{~s} & \\ & \text { to } & \text { to } & \text { to } \\ & 39 \mathrm{~s} & 53 \mathrm{~s} .3 \mathrm{~d} & 130 \mathrm{~s} .\end{array}$

(2) Railage 50 miles * $4 \mathrm{~s}: 6 \mathrm{~d} . \quad 7 \mathrm{~s} . \quad 130 \mathrm{~s}$.
(3) Cartage 4 miles* . 3s. 6d.

$\begin{array}{ll}7 \mathrm{~s} . & 7 \mathrm{~s} .\end{array}$

Cost per 100ft. . 47s.

Cost per chain $\overline{31 \mathrm{~s} .4 \mathrm{~d} .} \quad \overline{43 \mathrm{~s} .6 \mathrm{~d}} .99 \mathrm{~s} .4 \mathrm{~d}$.

* Varies with weights of tiles.

(Note.-No allowance is made for breakages. This máy be negligible with good tiles but can amount to 10 per cent. or more in the case of weak ones.)

\section{Cost of Tile Draining}

Actual cash outlay on tile draining will depend on the extent to which the farmer uses his normal farm labour or employs a contractor or casual labour.

For the purpose of presenting an example of cost it is assumed that a contractor is employed to dig the drains and backfill at so much per chain and that 
the farmer lays the tiles on the line, places them in the trench and attends to junctions and outfalls.

Contractors' charges for digging trenches and back-filling range from about $25 \mathrm{~s}$. to $45 \mathrm{~s}$. per chain. Taking the average of these figures and adding the cost of 4in. tiles landed on the farm, the cash outlay is likely to be of the order of $£ 318 \mathrm{~s}$. $6 \mathrm{~d}$. per chain to which the farmer may wish to add the cost of his own labour or that of his permanent staff.

So far as Taranaki is concerned I consider the cost per chain is likely to be from $5 \mathrm{~s}$. to $10 \mathrm{~s}$. (say $7 \mathrm{~s}$. 6d.) greater than the above, giving $£ 46 \mathrm{~s}$. per chain.

The reason for this is that the digging is likely to be more difficult than in most other areas because of the presence of stumps, boulders, etc.

\section{Drainage as a L ong-Term I nvestment}

The above figures of cost are discouraging until the position is examined from a long-term point of view, and it is from this angle that any land development must be viewed.

Taking an extreme case of land requiring drains at an average spacing of say 1 chain, at least 10 chains would be required per acre. (This is approximately the intensity of Mr Fox's tile drains, in one paddock at least). Well laid and properly maintained tiles should be effective for many years and in taking a 25-year term on which to base the estimates of the allocation of annual charges I consider I am being very conservative. At $\$ 46 \mathrm{~s}$. per chain 10 chains of drain would cost $\$ 43$ per acre. The cost per annum on a loan raised or surplus funds invested for a 25-year period on table mortgage with interest at $4 \frac{1}{8}$ per cent. is as follows:-

\section{Annual repayment of principal and interest on a loan of $£ 43$ on a 25 -year table mortgage at $4 \frac{1}{8}$ per cent.

$$
=55 \mathrm{~s} .6 \mathrm{~d} \text {. }
$$

The estimation of the net return likely to result from draining wet land is a much more difficult problem than arriving at the cost of draining. It is probably fair to say that the greater the need for draining the greater the cost and the greater the return, as $a$ general rule. Excepting peats, low-lying wet land is, as a rule, potentially fertile, the soil having been deposited in the form of eroded material from higher 
ground, enriched by the accumulation of organic matter from swamp vegetation.

For the purpose of estimating possible returns from drainage I can take' as an example either the complete development of a farm from a practically useless wet area or the development of a relatively unproductive portion of a farm on which the owner is already making a living.

I am using the latter example as applied to dairy farming because I think it would be more typical at the present time especially as applied to Taranaki.

A further assumption is made that the increase in cow numbers does not necessitate the employment of additional permanent labour.

The first question to be answered is:

W hat increase in carrying is likely to result from an expenditure of $\mathfrak{f} 43$ per acre on land needing draining so badly as to require such an outlay?

Experience in the Manawatu suggests that this may be of the order of $\frac{1}{4}$ cow per acre on land which is capable of carrying about $\frac{1}{2}$ cow per acre without drainage. Much land which is capable of carrying up to $\frac{3}{4}$ cow per acre, in an undrained condition is supporting more nearly 1 cow or nothing at all.

I propose to use the increase of $\frac{1}{4}$ cow per acre to illustrate possible returns from drainage.

For each extra cow carried there Will be certain extra items of cost. These would include:- Herd testing, farm stores and veterinary, repairs and maintenance, stock feed, extra labour at harvesting, interest on the value of the cow, etc., and can be set down at approximately £5 10s. per cow. (It must be remembered that fixed char,ges, such as wages of permanent staff, rates, interest, etc., will not be altered and are being borne already by the existing herd.)

On the basis of a production of 2801b. of butterfat per cow and $2 \mathrm{~s}$. $6 \mathrm{~d}$. per $\mathrm{lb}$. as the round figure price for butterfat, each extra cow would bring in a gross sum of $\$ 35$, plus a possible addition of $£ 4$ for cull stock and pigs. Deduct from this the extra costs of $£ 510 \mathrm{~s}$. and the net return per cow is $\$ 2910 \mathrm{~s} .{ }^{*}$ For $\frac{1}{4}$ cow, the estimated increased carrying per acre, the increased

* I am indebted to Mr Hodgson, Lecturer in Dairy Husbandry, Massey College, for the above estimate. 
net return is $\$ 77 \mathrm{~s}$. $6 \mathrm{~d}$. A summary of the above fol1 o $\quad$ W $\mathrm{s}$ : -

\section{Probable annual expenditure and income resulting from} the draining of 1 acre

\section{EXPENDITURE}

Interest and principal charges on investment of $\mathfrak{f} 43$ on 25 -year table mortgage at $4 \frac{1}{8}$ per cent.

$$
\text { \& s. d. }
$$

\section{INCOME}

Net return from $\frac{1}{4}$ cow producing $2801 \mathrm{~b}$. butterfat@2s.6d. lb.

Proceeds from sale of cull 'stock 'and pigs . 100

The reasonable expectation therefore, is that drainage will yield a margin of $\$ 512 \mathrm{~s}$. approximately per acre for each of the 25 years during which the repayment of the loan is taking place. After that time the drainage system, if properly maintained, will continue to yield handsome returns for many years.

The question may be asked: "What of the other costs such as ploughing, sowing to improved past-ure and topdressing "which will have to be done if the advantages of drainage are to be fully realised?"

My answer is that I appreciate the difficulty of divorcing any one factor in land improvement from associated factors but these other factors can, I think, stand on their own. If the land is so unproductive that all of these improvements, including drainage, must be carried out before any real benefit will result, the improvement in carrying capacity might well be not $\frac{1}{4}$ cow per acre, but from $\frac{1}{2}$ to $\frac{3}{4}$ cow and the increased returns will more than "compensate for the additional costs which also must be spread over a period of years.

\section{Financing Farm Drainage}

In this connection I would' merely state that if increased production of primary produce is really necessary and desirable-and I have no doubts regarding the importance of producing more food-then much 
of the assistance granted to ex-servicemen should be extended to young farmers of ability and integrity who, through no fault of their own are not ex-servicemen. I consider that, as a general principle the individual should be assisted not by grant and subsidies but by long-term loan at a reasonable rate of interest.

'Having been assisted to make sufficient from his farm to ensure a fair standard of living, plus some profit, he should be encouraged to effect further improvements likely to increase production by additional loans equal only to the surplus, small or large, which he is willing to invest himself.

\section{The Effect of Taxation, Relief}

The very commendable legislation introduced in 1950 to allow up to $£ 200$ of income spent on new drainage (and some other improvements) to be free of tax, must result in an increase in land drained.

There is, however, a rather' remarkable anomaly which I feel sure will be rectified if attention is drawn to the matter in the right place. It is. that, although income spent on the preparation of land for farming, including grassing, clearing of weeds, scrub, timber, pests, etc. is totally exempt from income and Social Security charges, drainage, which is the first essential in the development of much potentially highly fertile land is exempted only to the extent of $£ 200$.

It has been stated previously in this paper that an outlay of $£ 43$ on drainage should on a conservative estimate, cause a net increase in financial gain to the value of $£ 512 \mathrm{~s}$. per annum. Obviously such greater production will rapidly yield much more taxable income over the years than that forfeited by granting tax exemption on money spent on drainage.

I am, aware that all sorts of business organizations can advance the same argument, but the difference is that in this case increased tax-revenue and, non-edible goods will result, whereas increasing the production from the land will increase not only revenue from taxation but food also.

I feel there is an opportunity for those members of the legislature who sincerely believe that we should increase the production of food to prove their sincerity by supporting a.n extension of the income tax concessions already granted, along the lines suggested.

\section{Drainage Problems in Taranaki}

The remaining time at my disposal leaves very little opportunity for me to discuss technical aspects. 


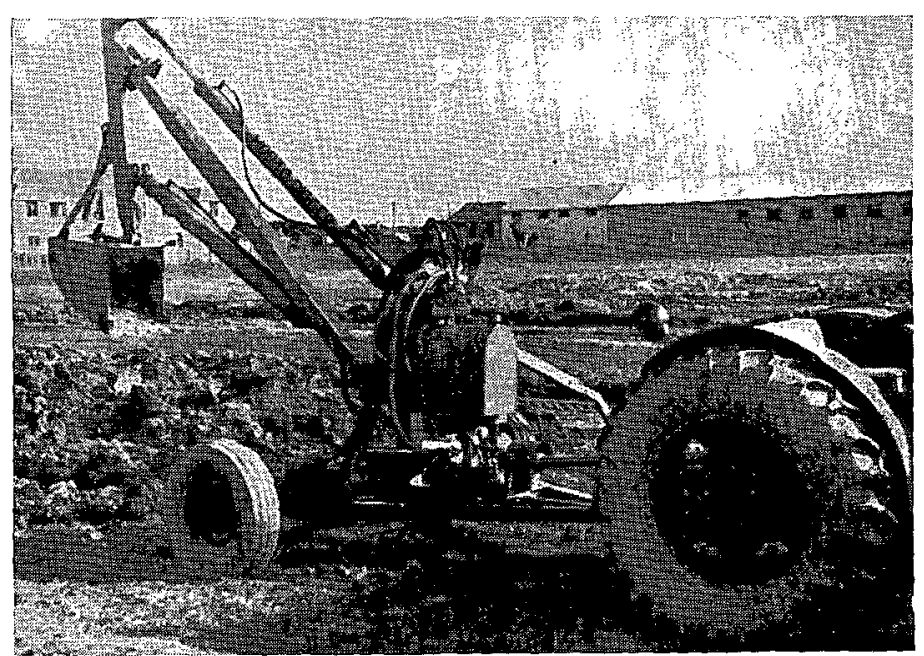

A hydraulically operated back-acter which can be towed behind a car and is capable of digging in stoney ground to a depth of $9 \mathrm{ft}$. The power required to drive the hydraulic pump can be supplied by a Jeep, Land-Rover, or tractor.

A "Priestman" Teredo bucket fitted to a Back Acter. This type of bucket can be used to dig comparatively narrow trenches suited to piles in soils containing stones or timber. The trenches can be dug to a fair grade with the assistance of a little hand work. Laying of the piles on fine gravel or clean well tamped soil enables final satisfactory grading to be accomplished.

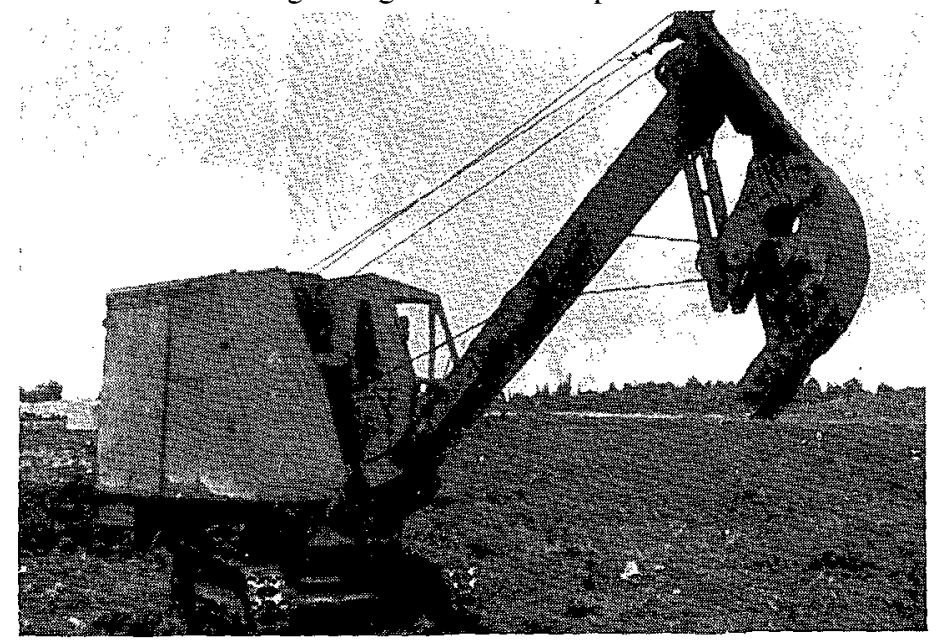


I hope, however, that you may have questions concerning your own problems with which I may be able to deal to your satisfaction.

Thanks to Mr Burgess, Instructor in Agriculture, New Plymouth, I was able, in a visit extending over about 11 days in September, to obtain, at least an insight into drainage problems in Taranaki. In addition Mr Eric McCallum has placed a report of a "subcommittee investigating soldier settlement" in Egmont County at my disposal.

Note.-Report of Sub-Committee of South Taranaki Federated Farmers Investigating Soldier Settlement, May 1947.

While this report does not mention drainage problems my observations lead me to suppose that of the 10,000 to $\mathbf{1 2 , 0 0 0}$ acres suggested as being in need of development, most of it would need to be drained before further development could proceed. The committee estimated a minimum potential of $1,000,000 \mathrm{lb}$. of butterfat from this land when developed. In addition much land already partly developed would benefit -to a marked degree from improved drainage. The Urenui and Uruti districts also have considerable need for drainage and I have no doubt there are numerous more localised areas in a similar position.

\section{Suggestions regarding methods of carrying out drain-} age in Taranaki.

(1) Types of machines needed. I wish to empha- sise at the outset that there is no one method of digging drains which is suitable for and applicable to all conditions unless it be that of hand digging. This latter is an increasingly unpopular type of work and machines must be used to an increasing extent.

The very irregular nature of the surface on most of the Taranaki wet land, the presence of stumps, boulders and in places ironstone, sandstone and compacted volcanic grit, militate against the efficient use of trench-digging machines of the rotary-wheel type. These may have a limited use but I gained the impression that the best trench digging machines are the drag-dozer, bulldozer, and the back-acter -types mounted on tracks. The latter, or the same machine with a bucket and dragline attachment for wider drains, is likely to be the only type suited to a great deal of the area.

Some attention should be given to the question of 
bucket size and design in the case of the back-acter, however. If tiles, are to be laid within $4 \mathrm{ft}$. or so from the surface a Teredo type of bucket 15 inches wide would provide ample width in which to work and lay tiles and would reduce the work of backfilling.

Where open drains are intended wider drains may be necessary. (Open drains should be avoided because of the cost of upkeep and the danger to stock.) This - will entail using the more conventional type of bucket' of greater width.

Alternatively, the drag-dozer and bulldozer can be used to open wide $\mathrm{V}$-drains to 18 to 24in. as a preliminary to increasing the depth some foot or so by hand and laying tiles when most of the water has been drained from the country.

An unfortunate tendency, when a machine capable of digging deeply is available, is to go to excess. I saw an example where drains up to 6 or $7 \mathrm{ft}$. deep were dug although with proper planning 3 or $4 \mathrm{ft}$. would have been not only ample but much easier and cheaper, and where tiles should have replaced open drains.

(Note.-A light American back-acter hydraulically operated and powered by power take-off of a tractor, Jeep or "Land Rover" offers prospects of being useful where stones and similar are not too large).

(2) The need for planning and surveying. Much effort and expense can be saved by a properly planned system and one where digging is done to predetermined grades. (Slides will be shown to illustrate a back-acter fitted with a Teredo bucket operating under such conditions.)

I see no prospect of proper planning unless the Department of Agriculture continues with its policy of training special Drainage Advisory Officers, who can survey and plan drain systems. Four capable and enthusiastic young men have been trained, but such a small number can do little toward providing the necessary surveys if a few energetic contractors commence trench digging in earnest,

If the Department of Agriculture is unable to provide the necessary trained technical service I see no reason why catchment boards or county councils should not do so. Such a service can pay' its own way especially in conjunction with machines hired out by the same bodies. 
Provision of Machines

The Ministry of Works has afforded wonderful service to. farmers in the Waimarino by hiring large bulldozers to carry out land clearing and drainage. The same assistance could be given in Taranaki if private. contractors, are not available. Alternatively, county councils or catchment boards, which almost always have the type of excavating machinery. required, could consider increasing their plant and providing technical service. Machines plus trained advisory officers could be charged for at a rate that would cover costs.

The scope for the use of machines in improving the general surface conditions is also very great. Some levelling of the ground surface would, in many cases, make cultivation easier and facilitate hay and silage making.

I trust what I have said may lead to some serious thought being given to the question of intensification of efforts to drain more of Taranaki's wet lands. Further, I hope most sincerely that thought will lead to action!

\section{DISCUSSION}

Q. What minimum spacing and' gradient would you consider necessary in tile draining stiff clays and consolidated peats on the Hauraki Plains?

A. This is rather a poser. My impression of the Hauraki Plain is that the production could be just about doubled with adequate drainage. There is an impression prevalent in the Plains area that the finer-textured soils cannot be drained by tiles because they are so compact, that water will not pass readily enough to the drains. The impression I gained from 'a recent visit to this area was that the finer textured soils, some of which had a clay or clay-loam subsoil, could be drained by a combination of moles and tiles. In other cases tiles only would be satisfactory: Satisfactory drainage by either moles or tiles would, however, be dependent on a more efficient system of main open drains to convey the water to the rivers. Since these main drains have flood gates to prevent water passing from the rivers into them during flood periods and high tides, they tend to become full during the period when the flood gates are closed.

The gradient in these drains is so flat that they do not empty satisfactorily when the flood gates open again. So long as this condition exists neither moles nor tiles are likely to be satisfactory except on areas which are high enough to have a satisfactory outfall which does not become submerged.

The answer to the proper draining of the Plains seems to lie in the installation of pumping schemes which will ensure 
the water in the main drains being kept below the level of outfalls from tiles.

I would think that the spacing of tiles might be anything from 1 to 3 or 4 chains, depending upon whether moles were being used in conjunction with them or not. Gradients in tiles as low as 1 in 500 could be used, although steeper gradients of 1 in 250 to 300 should be the minim\& where possible.

In view of the variable nature of peats and the controversy surrounding the proper means of developing them, I would prefer to leave the question of drainage of peats until $\mathbf{M r}$ Elliott's paper is discussed. 